\title{
Seasonal variability in bacterial abundance, production and protistan bacterivory in the lower Urdaibai estuary, Bay of Biscay
}

\author{
Arantza Iriarte*, Aitziber Sarobe, Emma Orive \\ Ekologia Laborategia, Zientzia eta Teknologia Fakultatea, Euskal Herriko Unibertsitatea (UPV/EHU), PK 644, \\ 48080 Bilbao, Spain
}

\begin{abstract}
Seasonal variations in abundance of heterotrophic bacteria, small $(1-8 \mu \mathrm{m})$ heterotrophic nanoflagellates (HNF), and ciliates, as well as bacterial production (BP) and bacterivory (PB) rates were investigated from May 1998 to May 1999 in the lower Urdaibai estuary (Bay of Biscay). Abundances ranged from $2.6 \times 10^{8}$ to $1.3 \times 10^{9}$ cells l $^{-1}, 0.65 \times 10^{6}$ to $3.00 \times 10^{6}$ cells l $^{-1}$, and 12 to 436 cells $\mathrm{l}^{-1}$ for bacteria, HNF and ciliates, respectively. BP varied between 0.9 and $18.5 \times 10^{8}$ cells $^{-1} \mathrm{~d}^{-1}$. Bacteria seemed to be more limited by food supply than by temperature. The major bacterivores were small HNF, but they could not satisfy their carbon demand only through bacterivory. Bacterivory rate per small HNF varied between 2.7 and 28.2 bacteria flagellate ${ }^{-1} \mathrm{~h}^{-1}$. This rate showed seasonal variations and was higher during late winter/early spring than during summer/early autumn. This pattern is probably due to the greater dependence of small HNF on bacteria during late winter/early spring, when the availability of food sources other than bacteria, e.g. autotrophic picoplankton, was low. This led to seasonal variations in the degree of grazing control on the bacterial standing stock, this control being tighter during late winter/early spring. Bacterivory rate was substantially higher than BP in many months, i.e. bacteria showed a negative growth, and this was paralleled by reduction in bacterial abundance. The relationship between log bacterial abundance and log small HNF abundance suggested that small HNF were largely under a substrate supply (bottom-up) control.
\end{abstract}

KEY WORDS: Bacteria $\cdot$ Bacterial production $\cdot$ Bacterivory $\cdot$ Heterotrophic nanoflagellates $\cdot$ Ciliates Estuary $\cdot$ Bay of Biscay

\section{INTRODUCTION}

Understanding the principles that govern trophic interactions among microbial planktonic organisms, i.e. those that regulate carbon and energy flows in microbial food webs, is a major goal in biological oceanography. One of the key questions to address is the mode of control of bacterial and heterotrophic protist abundances.

Since bacterial numbers in natural waters show little variation, it was suggested that bacterial production (BP) must be roughly balanced by grazing mortality (Sherr et al. 1989). However, the proportion of BP consumed by bacterivory is very variable, ranging from
$<50$ to $>100 \%$ (Sherr et al. 1986, Wikner et al. 1990). Methodological constraints may be partly responsible for these discrepancies (Sherr et al. 1986, Wikner et al. 1990), as well as other processes causing biomass losses, such as viral lysis (Fuhrman 1999). In addition to grazing and viral lysis, bacterial abundance and biomass can be controlled by physical factors, such as temperature and supply of substrates, through their effect on bacterial growth rates (Revilla et al. 2000, Schultz et al. 2003, Staroscik \& Smith 2004). However, it is recognized that the relative importance of the various factors that can regulate heterotrophic microbial population densities differs among systems (Wieltschnig et al. 1999) and also among seasons (Šolić et al. 1998). 
In many estuaries, temperature has been shown to exert a strong influence on bacterial activity (Schultz et al. 2003, McManus et al. 2004, Staroscik \& Smith, 2004). However, the influence of temperature has been shown to vary along the longitudinal axis in other estuaries (Goosen et al. 1997, Revilla et al. 2000). Furthermore, in some systems in which temperature has been shown to play an important role in shaping bacterial activity, temperature effects have been claimed not to override the influence of substrate availability (Murrell 2003, Apple et al. 2006). In estuarine ecosystems, control of substrate supply is more complex than in offshore waters due to potential spatial and seasonal variability in the proportion of autochthonous (e.g. primary production, zooplankton sloppy feeding) and allochthonous substrates used by bacteria.

The role of grazing in the control of bacterial standing stocks has been less studied. It has been suggested that grazing control is weaker in eutrophic than in oligotrophic waters (Boissoneault-Cellineri et al. 2001), and that the degree of grazing control also varies on seasonal time scales (Šolić \& Krstulović 1994).

Heterotrophic nanoflagellates (HNF) are generally reported as the main bacterivores (Weisse 1999, Ichinotsuka et al. 2006). However, the extent to which HNF can satisfy their carbon requirements through bacterivory is unclear. Some studies suggest that bacterivory can supply only a minor percentage of HNF carbon needs (Kuosa \& Kivi 1989, Vaqué et al. 1992), but it is not well known how widespread this situation is in marine and estuarine environments. The relative influence of substrate supply and/or predation in controlling the abundance of HNF in estuaries has been addressed in only a few studies (Mylaert et al. 2000, Iriarte et al. 2003).

In summary, there are still gaps in our understanding of the mechanisms that control the standing stocks of and carbon flows through bacteria and protists. In addition, few generalizations can be made because of the great heterogeneity across and within estuaries in terms of geomorphology, hydrography, nutrient and organic matter loading (McManus et al. 2004).

The lower Urdaibai estuary (Bay of Biscay) is characterized by high tidal flushing (the estuary almost empties itself with each tidal cycle), making it a relatively low-nutrient oligo-mesotrophic area. The aim of this study was to investigate the role of temperature, resources and grazing in the control of bacterial and HNF abundances in the lower Urdaibai estuary on a seasonal time scale. For this purpose, measurements of bacterial abundance and production rates, HNF and ciliate abundances, bacterivory rates, chl a biomass, and primary production rates were carried out during an annual cycle. Seasonal variations in bacterial abundance and production rates were measured in this estuarine zone in a previous work (Revilla et al. 2000) and bacterivory rates were measured in another study conducted in May 2001 (Iriarte et al. 2003). However, there is practically no information on HNF abundance and bacterivory rates on a seasonal time scale in the Urdaibai estuary, to enable us to compare the role of grazing, substrate supply and physical factors such as temperature, on bacteria and HNF.

\section{MATERIALS AND METHODS}

Study area and sampling scheme. The Urdaibai estuary is a temperate, small (area $\approx 1.89 \mathrm{~km}^{2}$, $\sim 12.5 \mathrm{~km}$ long), shallow (average depth of $3 \mathrm{~m}$ ), mesomacrotidal system draining to the Bay of Biscay, north of Spain (Fig. 1). The upper zone of the estuary is a narrow channel with limited tidal influence, and is rich in inorganic nutrients and organic matter. The lower zone is wider and has a central channel that is bordered by extensive tidal flats. Tidal advection exerts a major influence in the lower zone. The main geomorphological and hydrological characteristics of the Urdaibai estuary can be found in Villate et al. (1989).

In the present study, water masses of salinity $>34$ were selected in the lower reaches of the estuary, and sampling was carried out monthly at high tide from

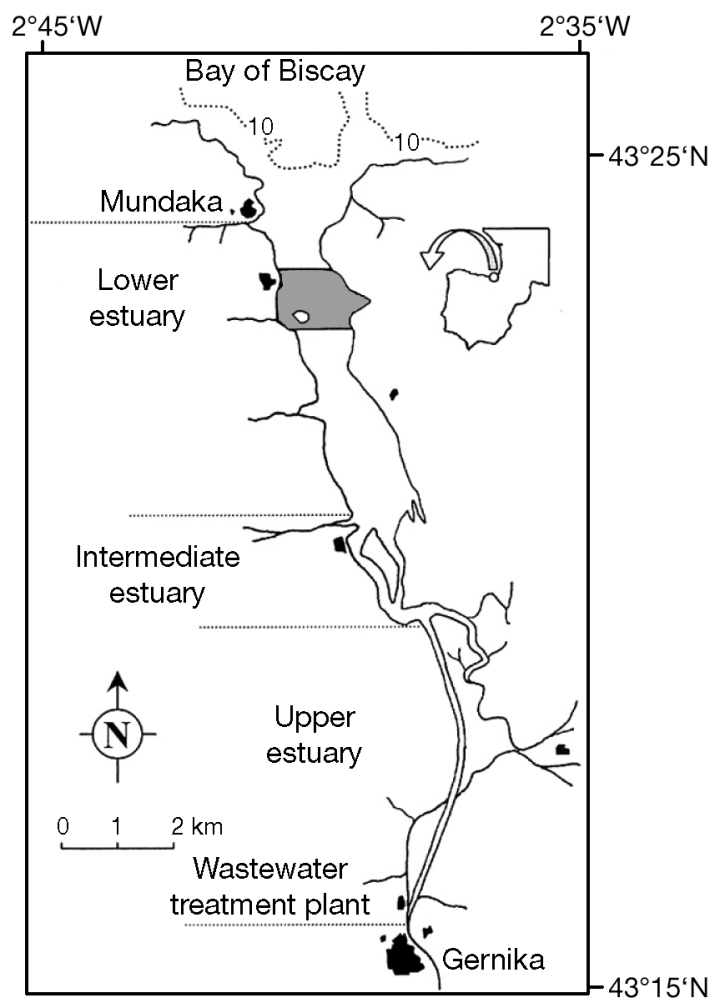

Fig. 1. Study area in the Urdaibai estuary, Bay of Biscay, and location of the sampling zone (shaded) 
May 1998 to May 1999 (Fig. 1). Water samples were taken near the surface $(0.5 \mathrm{~m})$ with a $5 \mathrm{l}$ Van Dorn opaque bottle, and temperature and salinity were measured in situ using an LF196 WTW sensor.

Inorganic nutrients. Samples filtered through Whatman GF/F filters were analysed for inorganic nutrients (nitrate, ammonium and phosphate) as described by Parsons et al. (1984).

Abundance of heterotrophic microbial plankton. Samples for the measurement of heterotrophic microbial plankton density were preserved with $1 \%$ glutaraldehyde. Aliquots of $100 \mathrm{ml}$ were filtered for counting ciliates, $50 \mathrm{ml}$ for small (1 to $8 \mu \mathrm{m}$ ) HNF (hereafter called small HNF), and $2 \mathrm{ml}$ for heterotrophic bacteria. All enumerations were performed on DAPI-stained samples using epifluorescence microscopy. A Leica DMRB microscope fitted with $40 \times$ and $100 \times$ (oil immersion) Pl-Fluotar objectives, and a Leica filter set for UV (set A with BP 340 to 380 excitation, RKP 400 beam splitter and LP 430 barrier filters) was used. For each bacterial sample, at least 750 bacteria and 30 fields were counted. For HNF, at least 150 individuals and 35 fields were counted, while the whole filter was scanned for ciliates.

Bacterial production and bacterivory. Bacterial net production (BP) was measured using the [methyl${ }^{3}$ thymidine] (TdR) incorporation method (Fuhrman \& Azam 1982). A detailed description of the methodology can be found in Iriarte et al. (2003). The mean CV of triplicate measurements was $28 \%$. Rates of TdR incorporation were converted to bacterial cell production rates applying a conversion factor of $2.514 \times 10^{18}$ cells mol $^{-1}$ (Iriberri et al. 1990).

Grazing rate on bacteria was measured using the radioactively labelled bacteria (RLB) technique (Caron et al. 1993). The methodology is described in detail elsewhere (Iriarte et al. 2003). Briefly, bacterivory was measured in 2 size fractions: 1 to 8 and 8 to $100 \mu \mathrm{m}$. For this purpose, samples were serially filtered through 8 and $1.2 \mu \mathrm{m}$ polycarbonate Millipore filters at the end of a 30 min incubation. Background radioactivity level was measured as incorporation of TdR in samples fixed with formaldehyde (2\% final concentration) at $t_{0}$. Radioactivity was measured as done for BP. The mean $\mathrm{CV}$ in triplicate measurements was $28 \%$ for the 8 to $100 \mu \mathrm{m}$ size fraction and $25 \%$ for the 1 to $8 \mu \mathrm{m}$ size fraction.

Protistan bacterivory $\left(\mathrm{PB}\right.$, in bacteria $\mathrm{l}^{-1} \mathrm{~h}^{-1}$ ) rates were calculated by converting the radioactivity retained on the filters into consumed bacteria, applying the same conversion factor as that used for BP.

Incubations for $\mathrm{BP}$ and $\mathrm{PB}$ were performed in ondeck type incubators equipped with a refrigerated circulator (FC 15 Grant Instruments) and a thermostatic heater (FH 16D Grant Instruments).
Bacterial-specific growth (BSG) rate was estimated as the ratio of BP to bacterial abundance (BA).

Chlorophyll $a$, primary production and extracellular release of carbon by phytoplankton. Chl a concentration was measured in 3 size fractions $(<1,1$ to 8 and 8 to $100 \mu \mathrm{m})$. Size fractionation was performed by filtration using polycarbonate Nuclepore filters. Chl a was extracted in $90 \%$ acetone and concentration was measured spectrophotometrically (Shimadzu UV 160A) as described by Parsons et al. (1984).

Primary production (PP) rate was measured using the ${ }^{14} \mathrm{C}$ technique (Parsons et al. 1984). Seawater samples were pre-filtered through a $100 \mu \mathrm{m}$ Nytal screen to eliminate larger zooplankton, and incubated for $24 \mathrm{~h}$ immediately after sampling in $60 \mathrm{ml}$ Nalgene bottles ( 1 dark and 3 light) with $4 \mu \mathrm{Ci} \mathrm{NaH}{ }^{14} \mathrm{CO}_{3}$. Incubations for PP were performed in the same incubator as for BP and PB. On-deck type incubations were carried out, simulating the in situ irradiance with neutraldensity screens. Incident PAR (photosynthetically active radiation) was recorded with a Li-Cor integrating quantum meter (Li-1000). At the end of the incubation, the bottle content was serially filtered through 8, 1.2 and $0.2 \mu \mathrm{m}$ pore-sized mixed cellulose ester filters with $47 \mathrm{~mm}$ diameter. The mean $\mathrm{CV}$ of triplicate measurements was $5.5 \%$.

Extracellular release of carbon (ERC) was estimated by measuring the radioactivity remaining in the filtrate after acidification, following the methodology described by Parsons et al. (1984), with the modification of using $1 \mathrm{~N} \mathrm{HCl}$ for acidifying the samples. Total $\mathrm{CO}_{2}$ concentration was estimated from alkalinity measurements (Parsons et al. 1984). The mean CV of triplicate measurements for ERC was $43.1 \%$.

Statistical analyses. Log transformations were performed on all data to meet requirements for normal distribution. Relationships between bacterial and phytoplankton parameters with other parameters were tested using Pearson product-moment correlation tests. A Student $t$-test was carried out to check for significant differences in BP between fractionated $(<1.2 \mu \mathrm{m})$ and unfractionated (total) samples. All statistical analyses were performed using SPSS software (SPSS 14).

\section{RESULTS}

\section{Abiotic parameters}

The temporal variation in selected hydrographic parameters in surface waters $(0.5 \mathrm{~m})$ are shown in Fig. 2. Salinity was $>34$ throughout the water column during the study period and temperature exhibited the typical seasonal pattern of temperate areas, with max- 

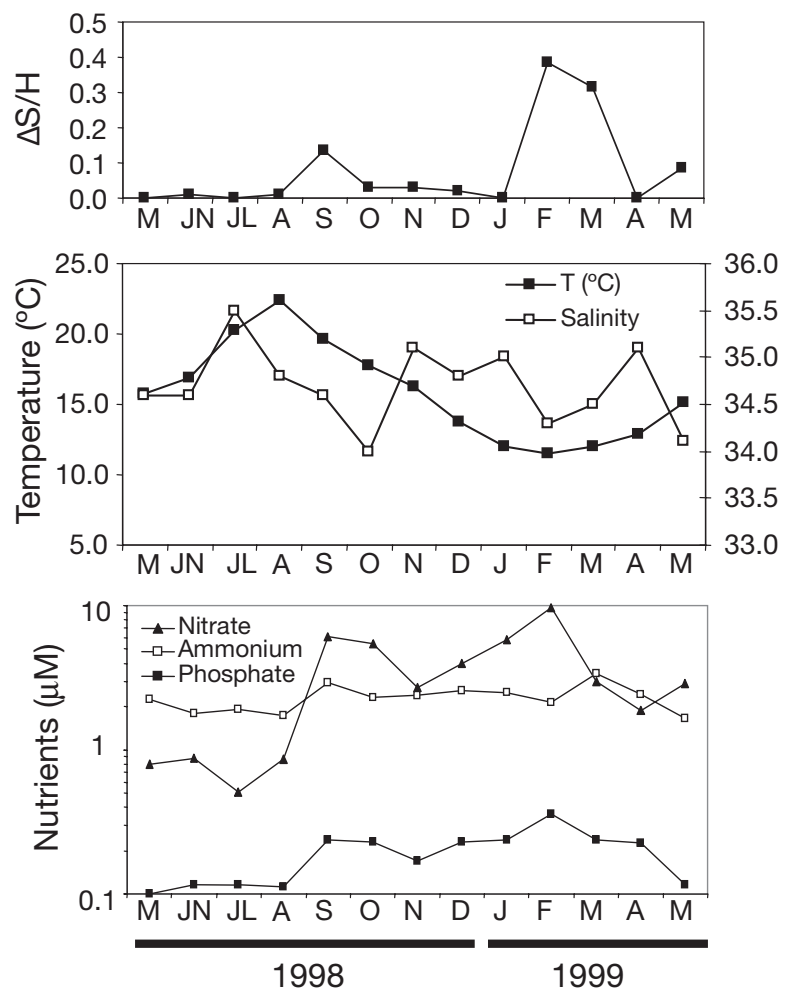

Fig. 2. Seasonal distribution of water column stratification index $(\Delta \mathrm{S} / \mathrm{H})$, salinity, temperature and nutrients (nitrate, ammonium and phosphate) in surface waters $(0.5 \mathrm{~m})$

imum values in summer $\left(22.4^{\circ} \mathrm{C}\right)$ and minimum in winter $\left(11.5^{\circ} \mathrm{C}\right)$. The stratification index $(\Delta \mathrm{S} / \mathrm{H})$ (Hoch \& Kirchman 1993) showed that this lower estuary was generally well mixed. A maximum value of 0.386 was measured in February, during high river flow rates.

Inorganic nutrient concentrations generally showed maxima in winter and minima in summer (Fig. 2). Phosphate concentration ranged from 0.06 to $0.36 \mu \mathrm{M}$ and was the scarcest of all the measured nutrients. Among the nitrogenous nutrients, nitrate was dominant during autumn and winter, and ammonium during summer (i.e. months of lowest river flow). Nitrate concentrations varied between 0.51 and $9.63 \mu \mathrm{M}$, and ammonium concentrations between 1.66 and $3.37 \mu \mathrm{M}$.

\section{Abundance of heterotrophic bacteria and protists}

BA varied between $2.6 \times 10^{8}$ and $1.3 \times 10^{9}$ cells l$^{-1}$. Maximum bacterial counts were measured in July, thereafter showing a general decreasing trend, and reaching a minimum value in February (Fig. 3). The 1 to $8 \mu \mathrm{m}$ size fraction was composed solely of HNF. The abundance of small HNF ranged from $0.65 \times 10^{6}$ to

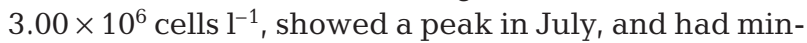

imum values in winter and April. The abundance of small HNF was more or less in phase with that of bacteria (Fig. 3). The abundance of ciliates was rather low and also peaked in July and March (Fig. 3).

The ratio of bacteria to small HNF ranged from 282 to 764 (mean $=458 \pm 132$ ). Log BA was significantly correlated with log small HNF $(r=0.79 ; \mathrm{p}<0.01)$. BA showed a positive correlation with temperature $(\mathrm{r}=$ 0.78; $\mathrm{p}<0.01)$ and PP $(\mathrm{r}=0.72 ; \mathrm{p}<0.01)$ (Table 1).

\section{Chlorophyll a, primary production, and extracellular release of carbon}

Chl a concentration, PP and ERC are presented in Fig. 4. Total chl a concentration varied between 0.4 and $1.4 \mu \mathrm{g} \mathrm{l}^{-1}$. The maximum concentration was registered in May 1998 and values were higher during summer and autumn than during winter. An important decline was observed from November to December and chl a remained low until February. It is interesting to note that chl $a$ in the $<1 \mu \mathrm{m}$ size fraction showed its maximum in August and also experienced a marked decline from November to December, remaining low thereafter.

The ERC varied between undetectable levels and $1.5 \mu \mathrm{g} \mathrm{Cl}^{-1} \mathrm{~d}^{-1}$. Maximum rates were measured in July, at the time of maximum BA and BP.
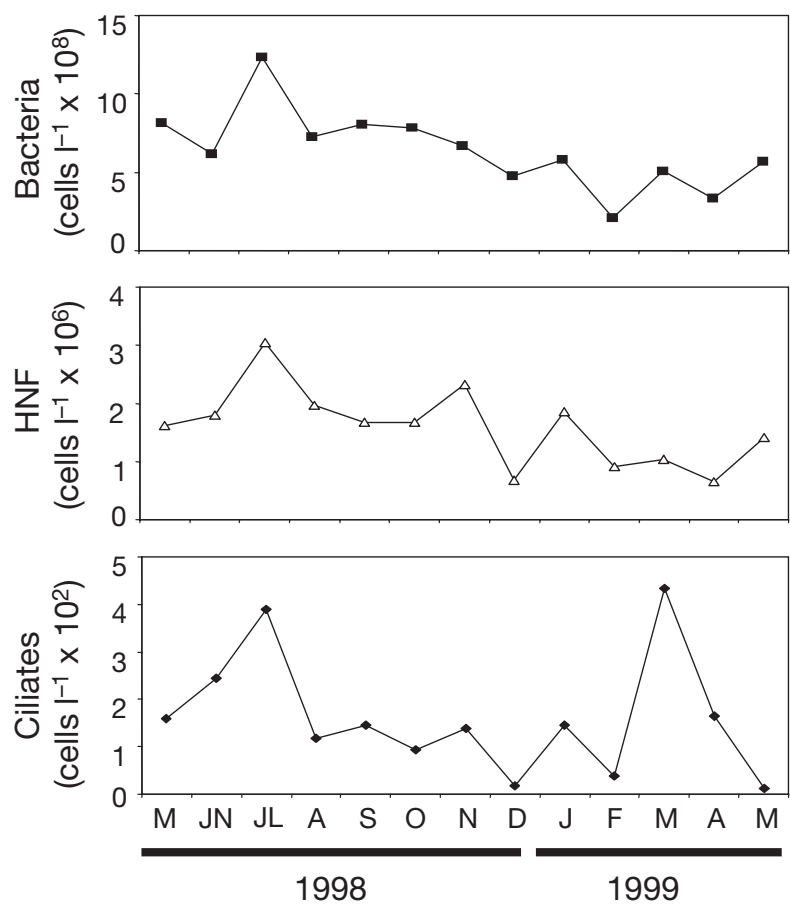

Fig. 3. Seasonal distribution of bacterial, small heterotrophic nanoflagellate (HNF) and ciliate abundances 
Table 1. Pearson correlation matrix of relevant log-transformed biotic and abiotic variables. T: temperature; S: salinity; BA: bacterial abundance; HNF: small heterotrophic nanoflagellate abundance; CA: ciliate abundance; BP: bacterial production in $<1.2 \mu \mathrm{m}$ size fraction; BSG: bacterial-specific growth rate; PB: protistan bacterivory; PP: total primary production; and ERC: carbon extracellular release rates. ${ }^{*} \mathrm{p}<0.05,{ }^{* *} \mathrm{p}<0.01$

\begin{tabular}{|c|c|c|c|c|c|c|c|c|c|c|c|c|c|}
\hline & $\begin{array}{c}\mathrm{T} \\
\left({ }^{\circ} \mathrm{C}\right)\end{array}$ & $\mathrm{NH}_{4}$ & S & BA & HNF & $\mathrm{CA}$ & $\mathrm{BP}$ & BSG & PB 1-8 & $\begin{array}{c}\text { PB } \\
8-100\end{array}$ & $\begin{array}{c}\text { PB } \\
\text { HNF }^{-1}\end{array}$ & $\begin{array}{c}\text { Chl } a \\
<1\end{array}$ & PP \\
\hline $\mathrm{NH}_{4}$ & -0.42 & & & & & & & & & & & & \\
\hline $\mathrm{S}$ & 0.15 & 0.04 & & & & & & & & & & & \\
\hline BA & $0.78^{* *}$ & -0.15 & 0.27 & & & & & & & & & & \\
\hline HNF & $0.68^{*}$ & -0.37 & 0.25 & $0.80^{* *}$ & & & & & & & & & \\
\hline CA & 0.21 & 0.29 & 0.48 & 0.40 & 0.41 & & & & & & & & \\
\hline BP & 0.31 & -0.15 & 0.12 & 0.40 & 0.39 & 0.43 & & & & & & & \\
\hline BSG & -0.17 & -0.02 & -0.05 & -0.16 & -0.05 & 0.20 & $0.83^{* *}$ & & & & & & \\
\hline PB 1-8 & -0.17 & 0.06 & 0.14 & -0.08 & -0.01 & 0.11 & $0.63^{*}$ & $0.80^{* *}$ & & & & & \\
\hline PB 8-100 & -0.34 & -0.27 & -0.12 & -0.31 & -0.40 & -0.17 & 0.20 & 0.53 & 0.30 & & & & \\
\hline PB $\mathrm{HNF}^{-1}$ & -0.55 & 0.27 & -0.04 & -0.55 & -0.62 & -0.17 & 0.24 & $0.66^{*}$ & $0.79^{* *}$ & 0.48 & & & \\
\hline Chl $a<1$ & $0.68^{*}$ & $-0.70^{* *}$ & 0.12 & 0.39 & 0.47 & -0.06 & -0.15 & -0.47 & -0.52 & -0.30 & $-0.70^{* *}$ & & \\
\hline $\mathrm{PP}$ & $0.73^{* *}$ & -0.33 & -0.01 & $0.72^{* *}$ & $0.63^{*}$ & 0.19 & $0.59^{*}$ & 0.19 & 0.01 & -0.36 & -0.39 & 0.48 & \\
\hline ERC & 0.23 & -0.42 & 0.58 & 0.42 & 0.50 & 0.52 & $0.65^{*}$ & 0.49 & -0.15 & 0.11 & 0.00 & 0.26 & 0.52 \\
\hline
\end{tabular}

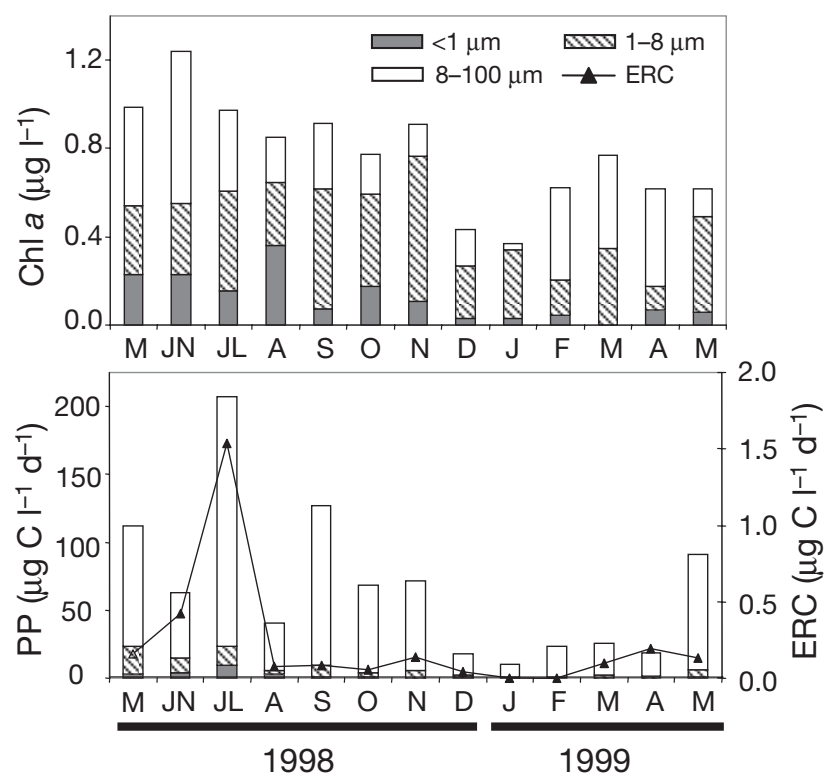

Fig. 4. Seasonal distribution of size-fractionated chl a biomass, primary production (PP) and carbon extracellular release rates $(\mathrm{ERC})$

\section{Bacterial activity}

BP in unfractionated samples varied between 0.9 and $18.5 \times 10^{8}$ cells $\mathrm{l}^{-1} \mathrm{~d}^{-1}$ throughout the annual cycle. BP also reached its maximum in July, but a second lower peak was registered in March, coinciding with the annual maximum in ammonium concentration (Fig. 5A). No significant difference $(t=-1.59$; $\mathrm{p}>0.05)$ in BP was noted between unfractionated and fractionated $(<1.2 \mu \mathrm{m})$ samples. BP showed a sig- nificant positive correlation with PP $(\mathrm{r}=0.59$; $\mathrm{p}<$ $0.05)$ and ERC $(r=0.65 ; \mathrm{p}<0.05)$, but not with temperature. BP was also significantly correlated with BSG, but not with BA. However, unlike BP, we were unable to see a significant correlation of BSG with PP (Table 1).

\section{Bacterivory}

PB per small HNF (Fig. 5B) varied between 2.7 and 28.2 bacteria flagellate $\mathrm{b}^{-1} \mathrm{~h}^{-1}$ (mean $\left.=10.5 \pm 8.2 \mathrm{SD}\right)$ and showed seasonal variations, with highest rates being measured in July (i.e. at the time of maximum BA and BP) and during winter and spring 1999. PB per small HNF showed a negative correlation with chl a concentration in the $<1 \mu \mathrm{m}$ size fraction (Table 1 ).

$\mathrm{PB}$ rates in the 1 to $100 \mu \mathrm{m}$ size fraction (Fig. 5C) varied approximately over an order of magnitude throughout the sampling period, ranging from $5.8 \times 10^{6}$ to $5.7 \times 10^{7}$ bacteria $\mathrm{l}^{-1} \mathrm{~h}^{-1}$. The seasonal distribution showed 2 periods of peak rates, i.e. June to July and February to March.

Small HNF contributed a mean of $63 \%$ to total bacterivory (Fig. 5C). In both size fractions, peaks in PB were observed in summer and winter (although in different months). PB rates in the 1 to $8 \mu \mathrm{m}$ size fraction showed a significant correlation with BP and BSG (Table 1). No such correlation was apparent for PB rates in the 8 to $100 \mu \mathrm{m}$ size fraction.

The proportion of BP consumed by heterotrophic protists was also highly variable throughout the study period, ranging from 28 to $405 \%$. However, except during 2 months, bacterivores consumed more than $50 \%$ of BP and a negative growth of bacteria was 

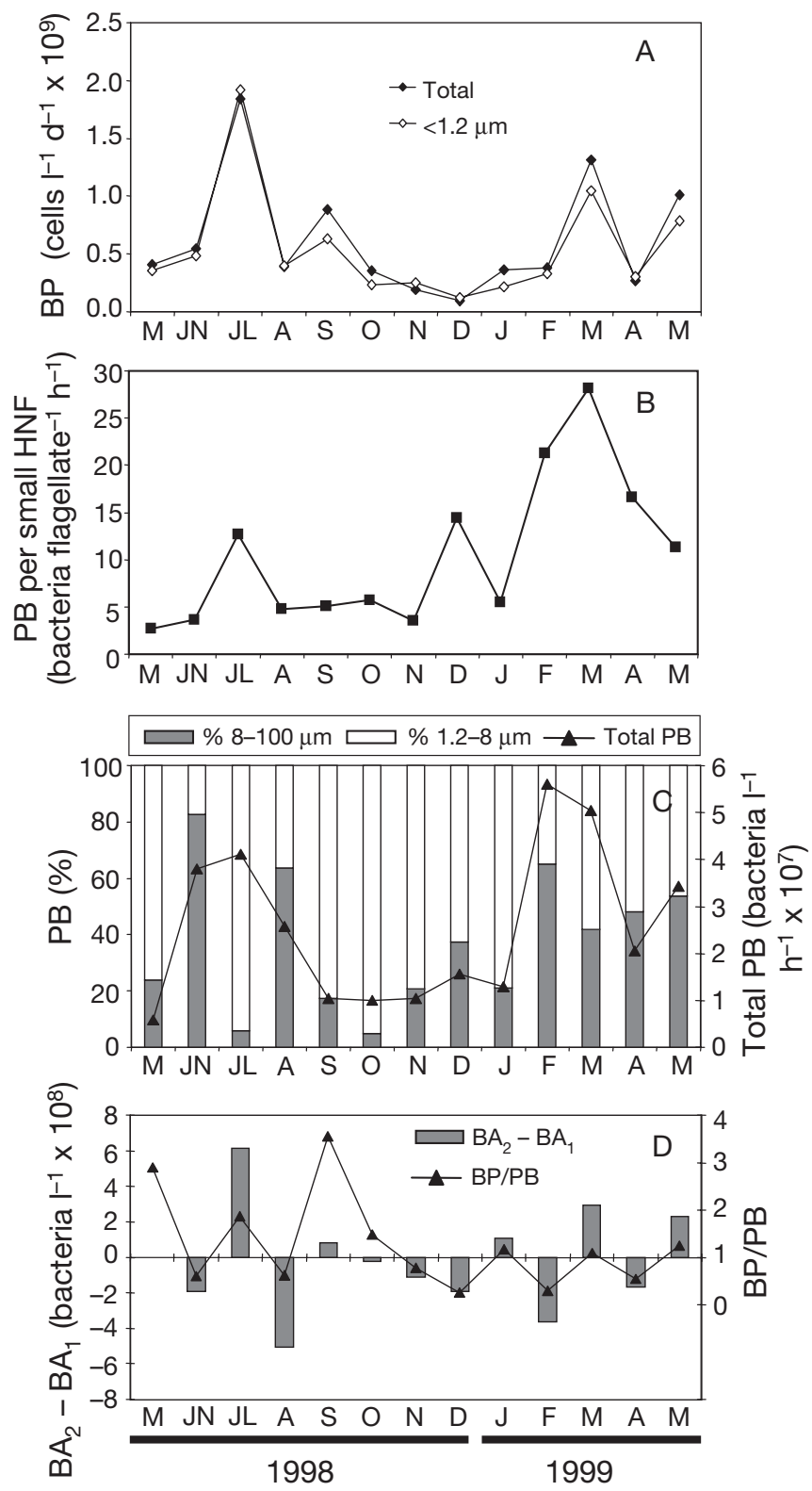

Fig. 5. Seasonal distribution of (A) bacterial production (BP) as measured in unfiltered and filtered $(<1.2 \mu \mathrm{m})$ samples, (B) protistan bacterivory rates (PB) per small heterotrophic nanoflagellate (HNF), (C) total protistan bacterivory rates (Total PB) and the percentage contribution of the 1 to 8 and 8 to $100 \mu \mathrm{m}$ size fractions to total protistan bacterivory, and (D) $\mathrm{BP} / \mathrm{PB}$ ratio and month to month variation in bacterial abundance $\left(\mathrm{BA}_{2}-\mathrm{BA}_{1}\right)$

observed (i.e. BP/PB < 1) during many months. Except for the October sample, monthly variations in bacterial biomass and the $\mathrm{BP} / \mathrm{PB}$ ratio showed the same tendency (Fig. 5D), i.e. when the BP/PB ratio was $<1$, BA also decreased in relation to its value in the previous month $\left(\mathrm{BA}_{2}-\mathrm{BA}_{1}<0\right)$. Conversely, when the $\mathrm{BP} / \mathrm{PB}$ ratio was $>1$, the $\mathrm{BA}$ increased from that in the previous month (Fig. 5D).

\section{DISCUSSION}

\section{Seasonal variation in bacterial production and growth rate}

Temperature has been shown to have a strong positive relationship with BP rate in many estuarine waters (Wright et al. 1987, Murrell 2003, Schultz et al. 2003, McManus et al. 2004, Staroscik \& Smith 2004), at least within a certain range of temperatures (Apple et al. 2006). This is also the case in the upper nutrient-rich zone of the Urdaibai estuary (Revilla et al. 2000). However, in the lower Urdaibai estuary, the present study has shown that BP does not significantly correlate with temperature. This is in agreement with previous results (Revilla et al. 2000), and a similar pattern has been observed in other low productivity, high salinity estuarine zones (e.g. the lower Schelde estuary, Goosen et al. 1997). It is noteworthy that a winter peak in BP coincided with a peak in ammonium, a nutrient derived primarily from sewage discharges in this estuary (Revilla et al. 2000). Wright et al. (1987) found a good correlation between BP and temperature in the Parker estuary, but they suggested that the role of temperature was only secondarily to determine the range within which microbial activity rates might vary. Instead, they suggested that the primary role of temperature was to govern the long-term supply of substrate from a variety of sources within the estuary. Apple et al. (2006) have also shown that in Monie Bay (Chesapeake Bay), the temperature effect on BP does not override the influence of substrate availability.

In the present study, BP showed a significant, though weak $(\mathrm{p}<0.05)$, correlation with PP by phytoplankton $>8 \mu \mathrm{m}$ in size. A good correlation between PP and BP has been reported in some coastal and estuarine waters (Cole et al. 1988), but not in others (Findlay et al. 1991, Almeida et al. 2005). In some estuaries PP and BP only show a positive relationship in their lower reaches (Goosen et al. 1997). In the present work, the July peak of BP coincided with a peak in ERC. BP was positively correlated with ERC but in general, the estimated rates of carbon exudation could account for only a small fraction $(<10 \%)$ of BP. A possible explanation for this could be that a high proportion of the photosynthetically derived carbon taken up by bacteria may come from sources other than phytoplankton exudation, e.g. dissolved organic matter released as a byproduct of protist or larger zooplankton feeding, as reported elsewhere (Hagström et al. 1988, Jumars et al. 1989). However, it is also likely that rates of ERC were underestimated due to uptake of part of the phytoplankton carbon exudates by bacteria during the incubation since the ${ }^{14} \mathrm{C}$ incubations were performed 
for periods of $24 \mathrm{~h}$. Therefore, the ERC data should be interpreted with some caution. Incubations of $24 \mathrm{~h}$ were chosen for PP to offset possible differences related to the time of day when incubations started, which depended on the timing of the high tide. In addition, dissolved organic carbon of anthropogenic origin also seems to play a role. Due to its primarily anthropogenic origin in this estuary (Revilla et al. 2000), ammonia can be taken as a proxy for allochthonous dissolved organic carbon. Despite the lack of correlation between BP and ammonia throughout the year, peak BP rates during autumn and winter occurred during peak ammonia events.

BP is a product of BA and BSG. The lack of correlation between BP and BA in the present data suggests that factors affecting $\mathrm{BP}$ are probably those affecting BSG. However, although BA and BP showed a positive correlation with $\mathrm{PP}$, we were unable to see a significant correlation between BSG and PP. Staroscik \& Smith (2004) were faced with a similar situation in Narragansett Bay and they argued that this could be due to the low precision of BSG owing to its being a derived parameter in which errors in each of the measured parameters could be compounded. However, it could also be an indication that substrates other than PP derived carbon could sometimes be an important substrate for bacteria in this estuarine zone.

It thus seems that bacterial activity in this estuarine zone is more dependent on food supply than on temperature, and that bacteria rely primarily on PP derived carbon although allochthonous carbon substrates can sometimes become important.

\section{Seasonal variation in bacterivory}

The percentage contribution of small HNF to total bacterivory (mean of $63 \%$ ) shows that the major bacterivores in the lower Urdaibai estuary are the small HNF. This appears to be a general trend in the marine environment (Wikner et al. 1990, Weisse 1999, Ichinotsuka et al. 2006), although in some areas such as tidal creek waters, ciliates can be responsible for the largest fraction of protozoan consumption of bacteria (Sherr et al. 1989).

The mean and range of PB per small HNF observed in the present study (mean 10.5; range 2.7 to 28.2 bacteria flagellate ${ }^{-1} \mathrm{~h}^{-1}$ ) are in good agreement with PB per HNF reported for the Hudson estuary from May to October (mean 8.5; range 1 to 19 bacteria flagellate ${ }^{-1}$ $\mathrm{h}^{-1}$ ) by Vaqué et al. (1992).

Bacterial grazing rates per HNF have been shown to vary seasonally. Šolić \& Krstulović (1994) observed these rates to be higher during the high temperature season than during the low temperature winter in
Kastela Bay. Vaqué et al. (1992) showed that they were low in May and June and higher from July to October in the Hudson estuary. Barcina et al. (1992) reported that ingestion rates per HNF were, in general, higher during the warm season than during winter for coastal waters in the Bay of Biscay. However, the variability in each month was as high as the seasonal variability in the latter study, since an 8-fold difference in ingestion rates per flagellate cell was observed on 2 different days in August. In the present study, PB per small HNF was high during warm months, but also in some lower temperature months. However, the abundance of small HNF did not show high values in winter. This variability in PB per small HNF may be due to the fact that they are able to use carbon sources other than bacteria, e.g. picophytoplankton and small nanophytoplankton (Kuosa \& Marcussen 1988, Caron et al. 1991), viruses and virus-sized particles (Gonzalez \& Suttle 1993), high molecular weight dissolved organic carbon (Sherr 1988), or even other heterotrophic nanoplankton (Havskum \& Hansen 1997). Furthermore, bacterivory rates in some areas can only satisfy a minor proportion of the carbon required for heterotrophic flagellate growth, at least during part of the annual cycle (Vaqué et al. 1992, Wieltschnig et al. 1999). A partial explanation for the pattern observed in the Urdaibai estuary could be that small HNF complement their diet with other carbon sources and that, during periods when the availability of carbon sources other than bacteria declines, small HNF ingest proportionately more bacteria. For example, chl $a$ in the $<1 \mu \mathrm{m}$ size fraction was observed to decrease sharply in late autumn and winter months and PB per small HNF showed an inverse correlation with chl $a$ in the $<1 \mu$ m size fraction.

Assuming for HNF an average doubling time of $2 \mathrm{~d}$ (Weisse 1999), a gross growth efficiency of $30 \%$ (Fenchel 1982), a mean volume of $27 \mu^{3}$ cell $^{-1}$ (direct measurement) and a volume to carbon biomass conversion factor of $0.22 \mathrm{pg} \mathrm{C} \mathrm{mm}^{-3}$ (Børsheim \& Bratbak 1987); and a carbon content of $20 \mathrm{fg} \mathrm{cell}^{-1}$ for bacteria (Lee \& Fuhrman 1987); it can be seen that PB by small HNF could satisfy only 13 to $27 \%$ of small HNF carbon demand during summer and autumn (with the exception of the July peak of BP and PB), whereas it generally satisfied more than $50 \%$ of small HNF carbon demand during winter and spring. In a eutrophic backwater environment, Wieltschnig et al. (1999) found that HNF covered only a seasonal mean of $21 \%$ of their carbon demand through bacterivory, and values as low as $5 \%$ were estimated for some months.

Other possible factors affecting the seasonal pattern of PB per HNF cell could be seasonal variations in the taxonomic composition of flagellates and/or in the size of bacteria, which may significantly affect bacterivory rates (Eccleston-Parry \& Leadbeater 1994). 
The reported percentages of BP consumed by heterotrophic flagellates in the marine environment vary over a wide range. Some studies suggest this percentage to be generally < $50 \%$ (Leakey et al. 1996, Tuomi et al. 1999), while other results suggest it to be about $50 \%$ (Sherr et al. 1986). Capriulo et al. (1991) and Christaki et al. (1999) suggested that BP is roughly balanced by grazing, while Wikner et al. (1990) and Coffin \& Connolly (1997) reported substantially higher bacterivory rates than $\mathrm{BP}$, at least during part of the year. Our data suggest that the main fate of BP in the lower Urdaibai estuary was bacterivory. During many months, PB was substantially higher than BP, i.e. bacteria showed a negative growth, and this was paralleled by a declining trend in BA. Besides pointing to the important role of grazing in the control of $\mathrm{BA}$, the coherent trends in the $\mathrm{BP} / \mathrm{PB}$ ratio and the difference in $\mathrm{BA}\left(\mathrm{BA}_{2}-\mathrm{BA}_{1}\right)$ suggest that monthly measurements are able to reflect general tendencies. However, BP, PB and the BP/PB ratio can all have significant daily variations (Iriarte et al. 2003) and this was reflected in the lack of correlation between $\mathrm{BP} / \mathrm{PB}$ and $\mathrm{BA}_{2}-\mathrm{BA}_{1}$.

\section{Factors controlling bacterial abundance: grazing, substrate supply and temperature}

A previous study showed that there is tighter control of bacteria by small HNF grazing in the lower estuary of Urdaibai than in its nutrient-rich zones (Iriarte et al. 2003). Results from the present study suggest that, in general, bacteria in this lower estuary were more tightly controlled by grazing during periods in which flagellates were presumably more severely limited by availability of carbon sources other than bacteria (e.g. phytoplankton).

Regarding substrate supply and/or temperature controls; the significant correlation between BA and PP, and between BP and PP, suggest that substrate limitation is stronger than temperature limitation as discussed above, although we were unable to see a significant correlation between BSG and PP or ERC. The positive correlation between BA and temperature can be explained by the high PB in some winter months. These results are in agreement with findings of Pace \& Cole (1996) that BP in lakes increased more rapidly upon fertilization than did abundance due to limitation of BA by bacterial predators.

\section{Grazing and substrate control of heterotrophic nanoflagellate abundance}

The ratio of BA to HNF abundance is estimated to be $\sim 1000$, in both freshwater and saltwater ecosystems
(Sanders et al. 1992). However, it is common to find large departures from this generalised ratio (Sanders et al. 1992, Gasol \& Vaqué 1993) since heterotrophic nanoplankton abundance seems to vary over a much narrower range than BA does across systems (Gasol \& Vaqué 1993). In view of the weak relationship they found between bacterial biomass and HNF abundance using a large data set, Gasol \& Vaqué (1993) derived an equation to calculate the maximal flagellate concentration attainable (MAA) for a given BA. Gasol (1994) generated a model to assess the main mode of control of HNF abundance in plankton systems. This model, in addition to the equation to generate the MAA line, contains an equation to calculate the MRA (mean realized abundance) line, which averages the effect of both bottom-up (substrate supply) and topdown (grazing) types of regulation throughout the year (Gasol 1994). According to Gasol's model, points lying far below the MRA line would indicate a clear topdown control on HNF abundance. Points above the MRA line would indicate that the top-down effect on HNF is low, and points close to the MAA line would indicate a clear bottom-up control. Applying this model to our data, it is apparent that top-down control on small HNF would be low in the lower Urdaibai estuary and that control would mainly be bottom-up since observations of log BA and log small HNF lie between the MAA and MRA lines (Fig. 6). This is consistent with the low ciliate densities, the lack of a significant correlation between small HNF and ciliates, and the significant correlation between small HNF and BA that were observed. The lower Urdaibai estuary is a relatively low nutrient zone and these results are in

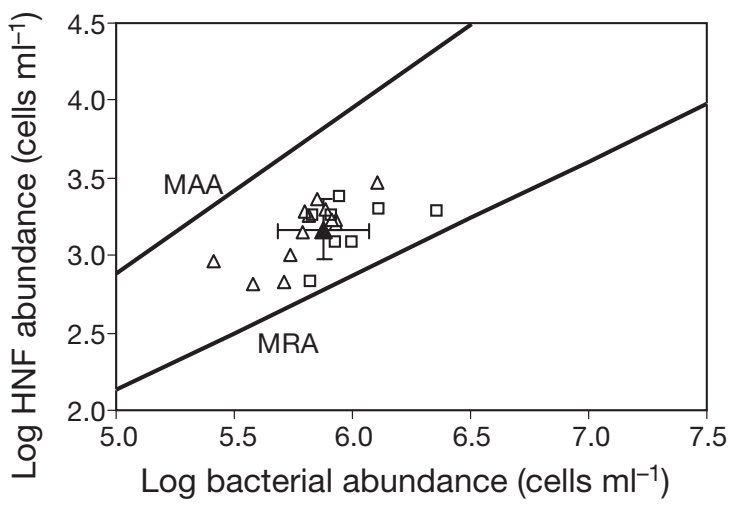

Fig. 6. Relationship between bacterial and small HNF abundances. Data used are from the present study obtained in May 1998 to May $1999(\Delta)$ and from Iriarte et al. (2003) obtained in May 2001 at Stn 1 in the euhaline zone of the Urdaibai estuary $(\square)$. $\mathbf{\Delta}$ : mean \pm SD of all data. The MAA line (maximum attainable HNF abundance) was plotted according to the model by Gasol (1994) (Eq. 1 in Table 3 therein). The MRA line (mean realized abundance) was plotted according to Gasol (1994) (Eq. 8 in Table 4 therein) 
agreement with observations of a dominant bottom-up control of HNF in oligotrophic sites (see Gasol 1994).

\section{CONCLUSIONS}

The lack of correlation between BP and temperature, and the positive correlation between $\mathrm{BP}$ and $\mathrm{PP}$, and between BP and ERC by phytoplankton suggest that substrate supply exerts a more important control than temperature on BP and growth.

Small HNF consumed larger amounts of bacteria than ciliates did, but bacteria were not the only food supply for small HNF since it was shown that they could not satisfy their carbon demand through bacterivory alone. Small HNF seemed to ingest proportionately more bacteria during late winter/early spring when the availability of food sources other than bacteria, e.g. autotrophic picoplankton, was low. This led to seasonal variations in the degree of grazing control of the bacterial standing stock, this control being tighter during late winter/early spring. During many months, PB was substantially higher than BP, i.e. bacteria showed a negative growth, and this was paralleled by decreases in BA.

In view of these considerations, we believe that bacteria in the lower Urdaibai estuary were under both substrate supply (bottom-up) and grazing (top-down) types of control, although it is difficult to establish which of the two exerted a tighter control. However, the relationship between BA and small HNF abundance and the lack of correlation between small HNF and ciliates suggested that small HNF were largely under a substrate supply (bottom-up) control.

Acknowledgements. This research was funded by the University of the Basque Country (UPV 118.310.-EB124/97) and the Department of Education, Universities and Research of the Basque Government (GV PI-1997-68). A.S. was supported by a grant from the Department of Education, Universities and Research of the Basque Government. We thank A. Ansotegui, J. M. Trigueros and I. Urrutxurtu for assistance in the field. We also thank Astilleros de Murueta S. A. for use of their shipyard facilities during the surveys.

\section{LITERATURE CITED}

Almeida MA, Cunha MA, Alcântara F (2005) Relationship of bacterioplankton production with primary production and respiration in a shallow estuarine system (Ria de Aveiro, NW Portugal). Microbiol Res 160:315-328

Apple JK, del Giorgio PA, Kemp MW (2006) Temperature regulation of bacterial production, respiration, and growth efficiency in a temperate salt-marsh estuary. Aquat Microb Ecol 43:243-254

Barcina I, Ayo B, Unanue M, Egea L, Iriberri J (1992) Comparison of rates of flagellate bacterivory and bacterial production in a marine coastal system. Appl Environ Microbiol $58: 3850-3856$
Boissoneault-Cellineri KR, Mehta M, Lonsdale DJ, Caron DA (2001) Microbial food web interactions in two Long Island embayments. Aquat Microb Ecol 26:139-155

Børsheim KY, Bratbak G (1987) Cell volume to carbon conversion factors for a bacterivorous Monas sp. enriched from seawater. Mar Ecol Prog Ser 8:211-223

Capriulo GM, Sherr EB, Sherr BF (1991) Trophic behaviour and related community feeding activities of heterotrophic marine protists. In: Reid PC, Turley CM, Burkill PH (eds) Protozoa and their role in marine processes. SpringerVerlag, Berlin, p 219-265

Caron DA, Lim EL, Miceli G, Waterbury JB, Valois FW (1991) Grazing and utilization of chroococcoid cyanobacteria and heterotrophic bacteria by protozoa in laboratory cultures and a coastal plankton community. Mar Ecol Prog Ser 76: 205-217

Caron DA, Lessard EJ, Voytek M, Dennett MR (1993) Use of tritiated thymidine (TdR) to estimate rates of bacterivory: implications for label retention and release by bacterivores. Mar Microb Food Webs 7:177-196

Christaki U, Van Wambeke F, Dolan J (1999) Nanoflagellates (mixotrophs, heterotrophs and autotrophs) in the oligotrophic eastern Mediterranean: standing stocks, bacterivory and relationships with bacterial production. Mar Ecol Prog Ser 181:297-307

Coffin RB, Connolly JP (1997) Bacteria and heterotrophic microflagellate production in the Santa Rosa Sound, Florida. Hydrobiologia 353:53-61

> Cole JJ, Findlay S, Pace ML (1988) Bacterial production in fresh and saltwater ecosystems: a cross-system overview. Mar Ecol Prog Ser 43:1-10

- Eccleston-Parry JD, Leadbeater BSC (1994) A comparison of the growth kinetics of six marine heterotrophic nanoflagellates fed with one bacterial species. Mar Ecol Prog Ser 105:167-177

> Fenchel T (1982) Ecology of heterotrophic microflagellates. II. Bioenergetics and growth. Mar Ecol Prog Ser 8:225-231

Findlay S, Pace ML, Lints D, Cole JJ, Caraco NF, Peierls B (1991) Weak coupling of bacterial and algal production in a heterotrophic ecosystem: the Hudson River estuary. Limnol Oceanogr 36:268-278

Fuhrman JA (1999) Marine viruses and their biogeochemical and ecological effects. Nature 399:541-548

Fuhrman JA, Azam F (1982) Thymidine incorporation as a measure of heterotrophic bacterioplankton production in marine surface waters: evaluation and field results. Mar Biol 66:109-120

$>$ Gasol JM (1994) A framework for the assessment of top-down vs. bottom-up control of heterotrophic nanoflagellate abundance. Mar Ecol Prog Ser 113:291-300

Gasol JM, Vaqué D (1993) Lack of coupling between heterotrophic nanoflagellates and bacteria: a general phenomenon across aquatic systems? Limnol Oceanogr 38:657-665

> Gonzalez JM, Suttle CA (1993) Grazing by marine nanoflagellates on viruses and virus-sized particles: ingestion and digestion. Mar Ecol Prog Ser 94:1-10

> Goosen NK, van Rijswijk P, Kromkamp J, Peene J (1997) Regulation of annual variation in heterotrophic bacterial production in the Schelde estuary (SW Netherlands). Aquat Microb Ecol 12:223-232

Hagström ^̊, Azam F, Andersson A, Wikner J, Rassoulzadegan F (1988) Microbial loop in an oligotrophic pelagic marine ecosystem: possible roles of cyanobacteria and nanoflagellates in the organic fluxes. Mar Ecol Prog Ser 49:171-178

> Havskum H, Hansen AS (1997) Importance of pigmented and colourless nano-sized protists as grazers on nanoplankton 
in a phosphate-depleted Norwegian fjord and in enclosures. Aquat Microb Ecol 12:139-151

Hoch MP, Kirchman DL (1993) Seasonal and interannual variability in bacterial production and biomass in a temperate estuary. Mar Ecol Prog Ser 98:283-295

Ichinotsuka D, Ueno H, Nakano S (2006) Relative importance of nanoflagellates and ciliates as consumers of bacteria in a coastal sea area dominated by oligotrichous Strombidium and Strobilidium. Aquat Microb Ecol 42:139-147

Iriarte A, Madariaga I, Revilla M, Sarobe A (2003) Short-term variability in microbial food web dynamics in a shallow tidal estuary. Aquat Microb Ecol 31:145-161

Iriberri J, Unanue M, Ayo B, Barcina I, Egea L (1990) Bacterial production and growth rate estimations from $\left[{ }^{3} \mathrm{H}\right]$ thymidine incorporation for attached and free-living bacteria in aquatic systems. Appl Environ Microbiol 44: 203-218

Jumars PA, Penry DL, Baross JA, Perry MJ, Frost BW (1989) Closing the microbial loop: dissolved carbon pathway to heterotrophic bacteria from incomplete ingestion, digestion and absorption in animals. Deep-Sea Res 36:483-495

Kuosa H, Kivi K (1989) Bacteria and heterotrophic flagellates in the pelagic carbon cycle in the Northern Baltic Sea. Mar Ecol Prog Ser 53:93-100

Kuosa H, Marcussen B (1988) Grazing of bacteria and phytoplankton by heterotrophic nanoflagellates in a Baltic Sea sample. Hydrobiologia 161:211-216

Leakey RJG, Archer SD, Grey J (1996) Microbial dynamics in coastal waters of East Antarctica: bacterial production and nanoflagellate bacterivory. Mar Ecol Prog Ser 142: $3-17$

- Lee S, Fuhrman JA (1987) Relationships between biovolume and biomass of naturally derived marine bacterioplankton. Appl Environ Microbiol 53:1298-1303

McManus GB, Griffin PM, Pennock JR (2004) Bacterioplankton abundance and growth in a river-dominated estuary: relationships with temperature and resources. Aquat Microb Ecol 37:23-32

Murrell MC (2003) Bacterioplankton dynamics in a subtropical-estuary: evidence for substrate limitation. Aquat Microb Ecol 32:239-250

Muylaert K, Van Mieghem R, Sabbe K, Tackx M, Vyverman W (2000) Dynamics and trophic roles of heterotrophic protists in the plankton of a freshwater tidal estuary. Hydrobiologia 432:25-36

Pace ML, Cole JJ (1996) Regulation of bacteria by resources and predation tested in whole-lake experiments. Limnol Oceanogr 41:1448-1460

Parsons TR, Maita Y, Lalli CM (1984) A manual of chemical and biological methods for seawater analysis. Pergamon, Oxford

Revilla M, Iriarte A, Madariaga I, Orive E (2000) Bacterial and phytoplankton dynamics along a trophic gradient in a shallow temperate estuary. Estuar Coast Shelf Sci 50: $297-313$

Editorial responsibility: Hugh Ducklow, Woods Hole, Massachusetts, USA
Sanders RW, Caron DA, Berninger UG (1992) Relationships between bacteria and heterotrophic nanoplankton in marine and fresh waters: an inter-ecosystem comparison. Mar Ecol Prog Ser 86:1-14

> Schultz GE Jr, White ED III, Ducklow HW (2003) Bacterioplankton dynamics in the York River estuary: primary influence of temperature and freshwater inputs. Aquat Microb Ecol 30:135-148

> Sherr BF, Sherr EB, Andrew TL, Fallon RD, Newell SY (1986) Trophic interactions between heterotrophic protozoa and bacterioplankton in estuarine water analyzed with selective metabolic inhibitors. Mar Ecol Prog Ser 32:169-179

Sherr BF, Sherr EB, Pedrós-Alió C (1989) Simultaneous measurement of bacterioplankton production and protozoan bacterivory in estuarine water. Mar Ecol Prog Ser 54: 209-219

Sherr EB (1988) Direct use of high molecular weight polysaccharides by heterotrophic flagellates. Nature 335:348-351

Šolić M, Krstulović N (1994) Role of predation in controlling bacterial and heterotrophic nanoflagellate standing stocks in the coastal Adriatic Sea: seasonal patterns. Mar Ecol Prog Ser 114:219-235

Šolić M, Krstulović N, Bojanić N, Marasović I, Ninãević Z (1998) Seasonal switching between relative importance of bottom-up and top-down control of bacterial and heterotrophic nanoflagellate abundance. J Mar Biol Assoc UK 78:755-766

Staroscik AM, Smith DC (2004) Seasonal patterns in bacterioplankton abundance and production in Narragansett Bay, Rhode Island, USA. Aquat Microb Ecol 35:275-282

Tuomi P, Lundsgaard C, Ekebom J, Olli K, Künnis K (1999) The production and potential loss mechanisms of bacterial biomass in the southern Gulf of Riga. J Mar Syst 23: 185-196

Vaqué D, Pace ML, Findlay S, Lints D (1992) Fate of bacterial production in a heterotrophic ecosystem: grazing by protists and metazoans in the Hudson Estuary. Mar Ecol Prog Ser 89:155-163

Villate F, Franco J, Ruiz A, Orive E (1989) Caracterización geomorfológica e hidrológica de cinco sistemas estuáricos del País Vasco. Kobie 18:157-170

Weisse T (1999) Bacterivory in the northwestern Indian Ocean during the intermonsoon-northeast monsoon period. Deep-Sea Res II 46:795-814

- Wieltschnig C, Wihlidal P, Ulbricht $\mathrm{T}$, Kirschner AKT, Velimirov V (1999) Low control of bacterial production by heterotrophic nanoflagellates in a eutrophic backwater environment. Aquat Microb Ecol 17:77-89

Wikner J, Rassoulzadegan F, Hagström $\AA$ (1990) Periodic bacterivore activity balances bacterial growth in the marine environment. Limnol Oceanogr 35:313-324

Wright RT, Coffin RB, Lebo ME (1987) Dynamics of planktonic bacteria and heterotrophic microflagellates in the Parker Estuary, northern Massachusetts. Cont Shelf Res 7: $1383-1397$

Submitted: March 19, 2008; Accepted: July 21, 2008

Proofs received from author(s): September 8, 2008 